\title{
Karakteristik Ruang Kampung Tambak Asri Berdasarkan Pendekatan Placemaking
}

\author{
Lidia Rubianto dan Ardy Maulidy Navastarai \\ Perencanaan Wilayah dan Kota, Fakultas Arsitektur Desain dan Perencanaan, \\ Institut Teknologi Sepuluh Nopember (ITS) \\ e-mail: ardy.navastara@urplan.its.ac.id
}

\begin{abstract}
Abstrak-Kampung Tambak Asri, Kelurahan Morokrembangan Kecamatan Krembangan Surabaya adalah kawasan permukiman yang berada di pinggiran kota. Kampung ini menunjukkan ciri-ciri ketidakberkelanjutan dalam fungsinya sebagai kawasan bermukim. Kondisi kumuh di lingkungan kampung Tambak Asri dan adanya kesenjangan sosial memberikan kesan yang kurang teratur di kampung ini. Kampung Tambak Asri juga dikenal sebagai Kampung Prostitusi yakni Kampung Kermil sejak tahun 1970an dan aktivitas ini ditutup oleh Pemkot Surabaya pada tahun 2012 lalu. Tambak Asri dengan tingkat kepadatan penduduk mencapai 10.198,6 jiwa/km². Angka kepadatan penduduk ini, turut merefleksikan kepadatan bangunan permukiman masyarakat. Di samping itu terdapat kondisi penggunaan ruang-ruang yang diabaikan. Terkait permasalahan tersebut, maka perlu untuk mengidentifikasi ruang-ruang Kampung Tambak Asri. Adapun tujuan penelitian ini adalah merumuskan karakteristik ruang-ruang Kampung Tambak Asri dalam perspektif space dan place. Pendekatan yang sesuai dalam perspektif space dan place adalah pendekatan placemaking. Placemaking adalah suatu cara bagaimana menciptakan sesuatu yang spesial baik dari dalam atau luar ruang atau space. Tahap awal penelitian ini dimulai dengan mengumpulkan data dan informasi melalui observasi, kuesioner responden masyarakat dan wawancara. Tahapan penelitian ini yakni mengidentifikasi karakteristik penggunaan ruang-ruang di Kampung Tambak Asri oleh masyarakat sebagai pengguna dengan metode statistik deskriptif. Karakteristik diidentifikasi berdasarkan indikator dan variabel terkait serta disajikan dengan pendekatan tematik. Hasil dari penelitian ini adalah karakteristik ruang-ruang kampung Tambak Asri dalam konteks space dan place berkaitan dengan pembangunan berkelanjutan.
\end{abstract}

Kata Kunci-Kampung, Placemaking, Space, Place, Tambak Asri.

\section{PENDAHULUAN}

$\mathrm{K}_{\mathrm{r}}^{\mathrm{A}}$ AMPUNG kota terbentuk dari sebuah aktivitas perkotaan yang muncul di kawasan pinggiran perkotaan. Suminttarsih dkk juga turut menjelaskan bahwa satuansatuan permukiman di kawasan kota yang dianggap sebagai tatanan permukiman tradisional sebelum masuknya perencanaan permukiman di Indonesia disebut dengan Kampung. Potensi sosial, ekonomi, budaya dan karakter bermukim di kampung dapat menjadi dasar paradigma baru dalam menata ruang yang berkualitas. Sehingga, Kampung dapat dijelaskan tumbuh dari kebutuhan bermukim masyarakat dengan ciri kehidupan didalamnya masih terdapat nilai-nilai sosial budaya masyarakat yang erat dengan nilai tradisional masyarakat setempat yang menjadi bagian dalam membentuk paradigma menata ruang yang berkualitas[1].

Salah satu faktor yang mempengaruhi perkembangan ruang terbuka Kota di Surabaya adalah adanya KampungKampung yang sadar lingkungan. Hal ini sangat erat berkaitan dengan salah satu value dari Kampung yang berkelanjutan. Artinya diperlukan swadaya dari masyarakat dalam memanfaatkan potensi ruang kampung untuk mendukung keberlanjutan[2].

Memahami perkembangan Kampung, Peneliti menyoroti Kampung Tambak Asri, Morokrembangan Surabaya yang berkembang di kawasan pinggiran Kota yang sudah ada sejak Jaman Penjajahan Belanda dengan perkembangan yang siginifikan pada aktivitas dalam ruang kampungnya. Kampung ini menunjukkan ciri-ciri ketidakberkelanjutan dalam fungsinya sebagai kawasan bermukim. Kondisi kumuh di lingkungan kampung Tambak Asri dan adanya kesenjangan sosial memberikan kesan yang kurang teratur di kampung ini.

Kampung Tambak Asri juga dikenal dengan Kampung Prostitusi yakni Kermil sejak tahun 1970an dan ditutup oleh Pemkot pada tahun 2012 lalu). Tambak Asri dengan tingkat kepadatan penduduk mencapai 10.198,6 jiwa/km², merefleksikan angka kepadatan penduduk yang tinggi. Selain itu, angka ini turut mengindikasikan adanya tingkat kepadatan bangunan yang tinggi. Sehingga, fakta- fakta tersebut menggambarkan kompleksitas permasalahan yang direkam dalam ruang Kampung Tambak Asri[3].

Berdasarkan hasil observasi, didapati kondisi undervalued pada penggunaan ruang Kampung Tambak Asri, yakni adanya ruang terbuka publik yang tidak dimanfaatkan secara aktif oleh masyarakat karena preferensi penggunaan ruang lainnya. Maksud dari ruang terbuka publik yang tidak dimanfaatkan dengan baik, digambarkan dengan adanya lapangan yang minim fasilitas dan jarang digunakan oleh masyarakat, taman bermain yang enggan digunakan oleh anak-anak, lahan kosong yang potensial tetapi digunakan untuk pembuangan sampah yang menciptakan kesan kumuh, serta aktifnya kegiatan masyarakat yang tidak berlangsung pada ruang-ruang yang tersedia sebagaimana mestinya. Hal ini menyebabkan adanya kondisi-kondisi penggunaan ruangruang (space) dalam Kampung yang diabaikan (useless) sehingga masyarakat cenderung tidak memaknai ruang tersebut dengan menjaga kualitas lingkungan

Untuk mengatasi kondisi penggunaan ruang secara undervalued, maka penting untuk mengidentifikasi karakteristik penggunaan ruang-ruang di Kampung Tambak Asri yang dilakukan dengan pendekatan placemaking. Placemaking adalah suatu cara bagaimana menciptakan sesuatu yang spesial baik dari dalam atau luar ruang (space)[4]. Placemaking memiliki prinsip yang dianggap sesuai untuk memberikan suasana hangat dalam membentuk sebuah place[5].

Berdasarkan pemaparan masalah di atas, memberikan pandangan bahwa perkembangan Kampung bukan lagi menjadi tatanan permukiman yang dibiarkan tumbuh dan berkembang dengan tidak terkendali penataannya. Sehingga, 
sangat penting untuk turut menyelesaikan permasalahan yang diuraikan pada latar belakang permasalahan di kawasan studi. Dengan memahami karakteristik ruang-ruang di dalam Kampung Tambak Asri melalui pendekatan placemaking dalam konteks mendukung keberlanjutan kawasan Kampung.

\section{METODE PENELITIAN}

\section{A. Jenis dan Pendekatan Penelitian}

Pendekatan yang digunakan dalam penelitian ini adalah pendekatan rasionalistik deduktif. Jenis penelitian dalam penelitian ini adalah deskriptif kualitatif[6].

\section{B. Variabel Penelitian}

Variabel penelitian yang digunakan pada tahapan penelitian ini adalah variabel kepadatan penduduk, kondisi prasarana dan sarana, kondisi lingkungan, karakter desa, penghasilan masyarakat, serta kegiatan dan usaha ekonomi.

C. Identifikasi Karakteristik Penggunaan Ruang-Ruang di Kampung Tambak Asri oleh Masyarakat sebagai Pengguna

Dalam melakukan identifikasi karakteristik penggunaan ruang-ruang di Kampung Tambak Asri,dilakukan proses analisa dengan metode statistik deskriptif dengan data yang disajikan dengan pendekatan tematik. Adapun langkah dalam proses analisa tahap ini adalah sebagai berikut :

1. Peneliti menyusun kuesioner berdasarkan indikator dan variabel penelitian (kondisi fisik, sosial dan ekonomi. Kuesioner bersifat semi terbuka, dengan responden warga Kampung Tambak Asri yang sesuai dengan kriteria responden penelitian.

2. Peneliti melakukan kompilasi hasil survei kuesioner (dalam bentuk diagram atau tabel deskripsi).

3. Hasil penelitian disajikan dengan pendekatan tematik. Tema terkait meliputi adaptasi, preferensi bermukim, serta pola dan progresivitas ruang kampung.

4. Ketiga tema ini disadur dari literatur dan hasil observasi gambaran umum wilayah. Peneliti menganalisa relevansi substansi indikator dan variabel dalam kuesioner dengan 3 tema di atas.

Sehingga, beragam unit informasi sesuai dengan variabel penelitian dapat dijelaskan secara tersistematis dalam tematema terkait sebagai karakteristik ruang kampung.

\section{HASIL DAN PEMBAHASAN}

A. Identifikasi Persepsi Penggunaan Ruang-Ruang di Kampung Tambak Asri oleh Masyarakat sebagai Pengguna

Dalam penelitian ini, wilayah studi berada dalam lingkup Kelurahan Morokrembangan Kecamatan Krembangan Surabaya Utara. Adapun dominasi penggunaan lahan pada wilayah studi adalah permukiman. Dengan luas wilayah kelurahan Morokrembangan mencapai 327 Ha dan proporsi cakupan luas wilayah studi mencapai 186, 3 Ha. Berikut batasan fisik kampung Tambak Asri Surabaya:

Sebelah Barat : Jl. Demak

Sebelah Timur : Jl. Tol Surabaya-Gresik

Sebelah Utara : Jl. Gresik Gadukan Timur - Jl. Kalianak Timur

Sebelah Selatan :Jl. Tol Surabaya Gresik- Jl.Raya Dupak

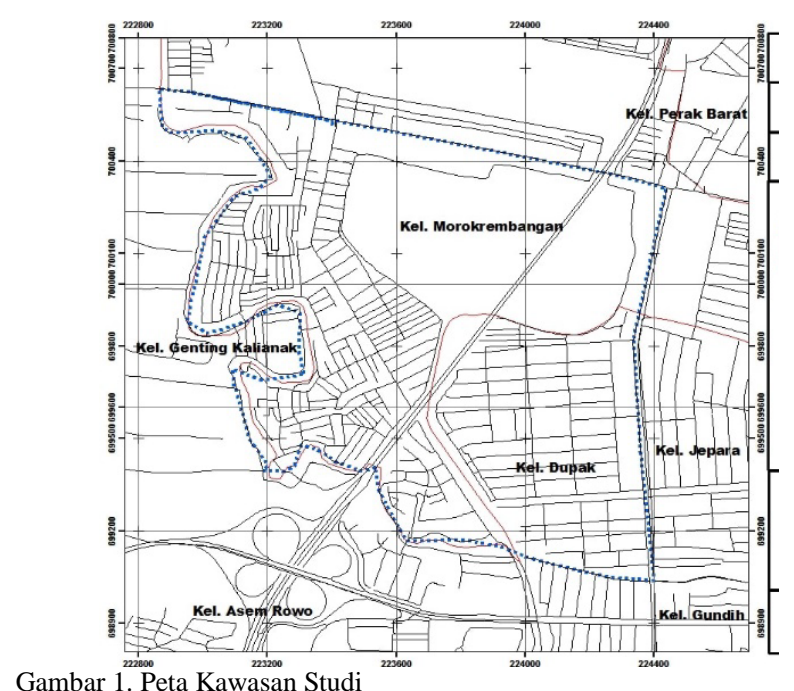

Gambar 1. Peta Kawasan Studi

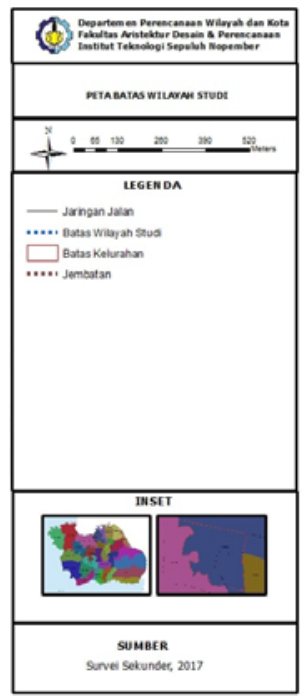

Gambar 2. Keterangan Peta Kawasan Studi

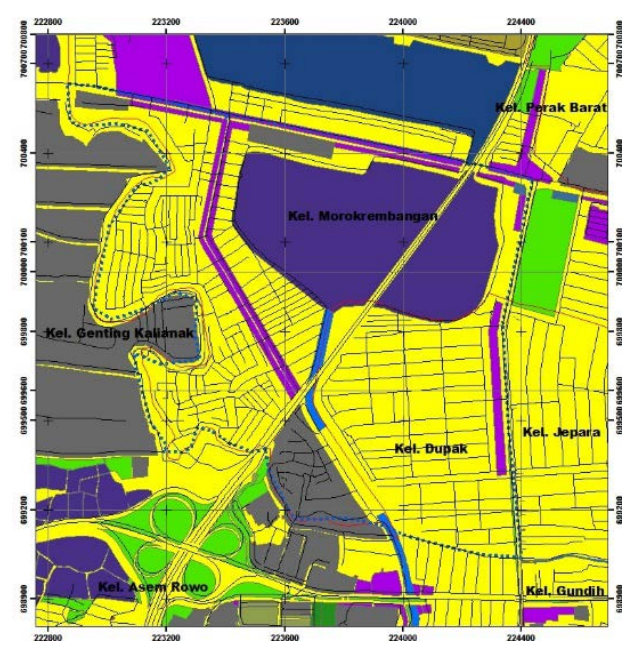

Gambar 3. Peta Penggunaan Lahan 


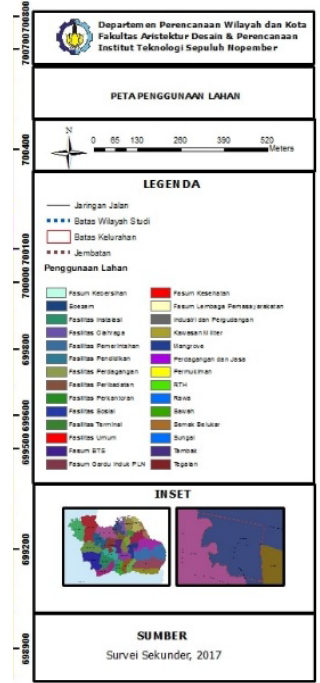

Gambar 4. Keterangan Peta Penggunaan Lahan

Unit sampling penelitian ini meliputi Jalan Tambak Asri Raya, jalan lingkungan (Gang XXV), sempadan sungai (1124,8 m), lahan kosong (jalan Tambak Asri Dalam), Taman Bermain, Lapangan sepak bola, Gardu (Gang XXV), dan Balai RW XI. Unit sampling ditentukan berdasarkan pertimbangan kebutuhan penelitian. Unit sampling ini akan menjadi sasaran setiap tahapan penelitian.
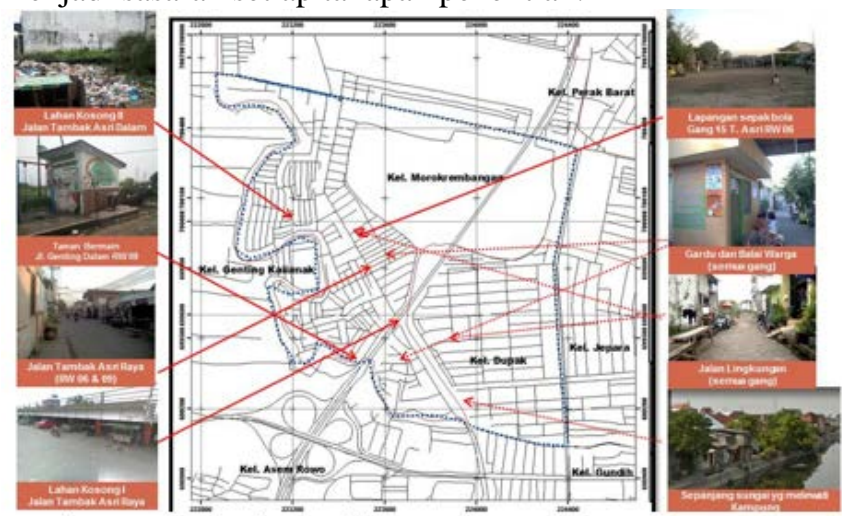

Gambar 5. Lokasi Unit Sampling

Tahapan awal penelitian adalah melakukan pengumpulan data melalui instrumen kuesioner dan hasilnya disajikan dengan pendekatan tematik diperoleh hasil seperti pada Tabel 1 .

Tabel 1.

Penjelasan Pendekatan Tematik Identifikasi Persepsi Penggunaan Ruang di Kampung Tambak Asri

$$
\text { SASARAN I }
$$

KARAKTERISTIK HUBUNGAN RUANG-RUANG KAMPUNG DAN MASYARAKATNYA SEBAGAI PENGGUNA

\begin{tabular}{|c|c|}
\hline Penjelasan Tematik & Unit Informasi \\
\hline \multicolumn{2}{|c|}{ 1. Adaptasi kondisi lingkungan ruang kampung } \\
\hline $\begin{array}{l}\text { Adaptasi kultural } \\
\text { terhadap kondisi fisik } \\
\text { ruang Kampung }\end{array}$ & $\begin{array}{l}\text { Responsi kondisi kebersihan lingkungan } \\
\text { Responsi kenyamanan bermukim }\end{array}$ \\
\hline $\begin{array}{l}\text { Adaptasi fisiologi } \\
\text { aktivitas sosial di ruang }\end{array}$ & $\begin{array}{l}\text { Jenis aktivitas sosial } \\
\text { Frekuensi kegiatan sosial }\end{array}$ \\
\hline Kampung & $\begin{array}{l}\text { Ruang yang ditempati } \\
\text { berlangsungnya aktivitas sosial }\end{array}$ \\
\hline
\end{tabular}

\section{Preferensi bermukim di Kampung Tambak Asri}

Preferensi kedekatan Kondisi ketersediaan sarana dan prasarana fasilitas dalam ruang- Identifikasi radius akses ke fasilitas umum ruang Kampung

\author{
Preferensi kelayakan Responsi kelayakan bermukim \\ sebagai \\ bermukim \\ Preferensi kawasan Aktivitas dan kegiatan ekonomi masyarakat \\ bermukim berdasarkan \\ faktor ekonomi
}

\section{Pola \& progresivitas ruang Kampung}

Penataan Fisik Ruang Pola permukiman

Kampung Tambak Asri Penataan fisik lingkungan

Orientasi perkembangan permukiman

Perkembangan ruang Perkembangan program pembangunan

kampung secara mandiri

dan bertahap

Karakteristik ruang Kampung Tambak Asri dipengaruhi penggunaannya oleh masyarakat. Kondisi Kampung saat ini merupakan produk dari interaksi masyarakat dengan lingkungan bermukimnya. Karakter ruang Kampung Tambak Asri berdasarkan tahapan ini dijelaskan bahwa dipengaruhi oleh proses adaptasi, preferensi bermukim serta pola dan progresivitas kampung. Tahapan ini sekaligus memberikan gambaran terkait ciri penggunaan ruang di Kampung Tambak Asri yang juga berlangsung pada unit sampling.

Karakteristik ruang Kampung Tambak Asri dapat dijelaskan secara tematik sebagai berikut :

1. Adaptasi

Masyarakat yang bermukim di Kampung Tambak Asri juga melewati fase adaptasi atau penyesuaian dengan kondisi lingkungan ruang kampung, baik masyarakat yang sudah mendiami sejak lama atau baru saja. Berdasarkan tema adaptasi peneliti merumuskan temuan sebagai berikut:

a) Adaptasi kultural terhadap kondisi fisik ruang Kampung

Kondisi lingkungan dapat dilihat secara fisik dari kebersihan lingkungan kampung. Pendapat responden menegaskan bahwa 64\% masyarakat Kampung Tambak Asri menilai bahwa lingkungan Kampung bersih. Di samping itu, 34\% responden masyarakat berpendapat bahwa lingkungan Kampung Tambak Asri dinilai kotor dan 2\% responden lainnya berpendapat sangat kotor. Disesuaikan dengan data observasi kondisi fisik dimana masih terdapat sampah yang berserakan di beberapa titik lahan kosong, maka standar kebersihan lingkungan yang diukur oleh masyarakat Kampung cukup beragam dan umumnya didasarkan pada kenyamanan selama bertempat tinggal. Bentuk kenyamanan bertempat tinggal tanpa disadari memberikan makna place karena interaksi sangat kental berlangsung di jalan lingkungan. Sehingga, Adanya sampah yang berserakan bukan lagi menjadi masalah lingkungan selama interaksi antar tetangga dan kenyamanan bermukim masih terjaga.

Peneliti mengaitkan data kondisi lingkungan di atas dengan data kenyamanan bermukim menurut masyarakat, dan diinformasikan bahwa 7\% sangat nyaman dan 89\% lainnya nyaman. Data ini sekaligus menegaskan bahwa umumnya masyarakat beradaptasi dengan kondisi lingkungan yang secara fisik apa adanya karena kenyamanan bermukim.

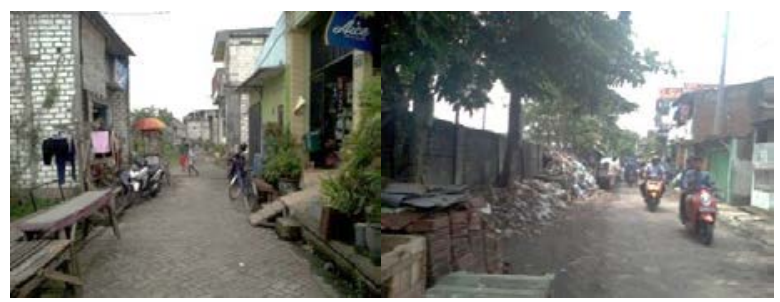

Gambar 6. Kondisi Lingkungan Kampung Tambak Asri 
b) Adaptasi Fisiologi Aktivitas Sosial di Ruang Kampung

Sisi adaptasi lingkungan lainnya dapat dilihat dari perspektif sosial masyarakat Kampung Tambak Asri. Adaptasi yang dipengaruhi oleh aktivitas penghuni dalam lingkungan hunian dan susunan ruang dalam lingkungan itu sendiri[7]. Dalam penelitian ini dapat diidentifikasi proses adaptasi fisiologi dalam kacamata masyarakat Kampung Tambak Asri.

Tabel 2.

Identifikasi Aktivitas Sosial Masyarakat dalam Ruang Kampung Tambak Asri

\begin{tabular}{lcl}
\hline \hline Jenis Aktivitas & Frekuensi & \multicolumn{1}{c}{ Ruang yang ditempati } \\
\hline Bertetangga & $\begin{array}{c}\text { Lebih dari dua } \\
\text { kali dalam } \\
\text { seminggu }\end{array}$ & $\begin{array}{l}\text { Pola hidup bertetangga dilakukan } \\
\text { dengan bertegur sapa atau di waktu } \\
\text { senggang berbincang bincang } \\
\text { (ngobrol) dengan tetangga lainnya. }\end{array}$ \\
& Aktivitas ini dapat berlangsung di \\
& tempat dudukan di tepi jalan \\
& lingkungan, ruamh warga lainnya \\
& yang sudah sering ditempati atau \\
& balai warga setempat.
\end{tabular}

$\begin{array}{cl}\text { Pengajian } & \text { Seminggu } \\ \text { sekali } & \text { masyarakat menjalin silaturahmi } \\ & \text { mengadakan pengajian bersama yang } \\ & \text { rutin dilakukan seminggu sekali dan } \\ & \text { berlangsung bergantian di rumah- } \\ & \text { rumah warga }\end{array}$

Senam

Bersama

Setiap

weekend, seminggu sekali

Kegiatan ini merupakan implementasi program yang dirumuskan oleh PKK setempat dan dikoordinasikan per RT.

Karena keterbatasan ruang, kegiatan ini sering diadakan di ruas jalan lingkungan Tambak Asri atau depan balai warga.

\begin{tabular}{|c|c|c|}
\hline $\begin{array}{l}\text { Pelatihan/ } \\
\text { workshop } \\
\text { bersama }\end{array}$ & eventual & $\begin{array}{l}\text { Kegiatan eventual ini dimaksudkan } \\
\text { untuk memberdayakan kemampuan } \\
\text { dan perekonomian masyarakat } \\
\text { setempat. }\end{array}$ \\
\hline
\end{tabular}

Kerja Bakti

Sebulan sekali Dengan tujuan menciptakan atau dua bulan lingkungan yang bersih, pengurus sekali organisasi masyarakat setempat juga mengagendakan kerja bakti membersihkan selokan dan timbunan sampah sekitar

$\begin{array}{lll}\text { Rapat } & \text { eventual } & \text { Aktivitas rapat organisasi atau } \\ \text { organisasi } & \text { komunitas diadakan dengan } \\ & \text { menggunakan balai warga atau } \\ & \text { rumah warga. }\end{array}$

Aktivitas pada eventual Acara tertentu lainnya yang diadakan ruang depan warga seperti pengajian, pernikahan, rumah kumpul keluaga besar umumnya menggunakan area teras atau jalan depan rumah.

Selain itu, ruang depan rumah dapat dimanfaatkan

Pelatihan/

eventual

workshop

bersama

Kegiatan eventual ini dimaksudkan untuk memberdayakan kemampuan dan perekonomian masyarakat setempat.

Adaptasi fisiologi aktivitas sosial juga digambarkan dengan intensitas penggunaan ruang-ruang kampung Tambak Asri. Sesuai dengan ciri dan karakter Kampung yang identik dengan guyub, sehingga ruang-ruang Kampung sangat dekat dengan aktivitas sosial masyarakat. Intensitas turut memberikan ukuran seberapa dekat interaksi masyarakat dengan ruang yang membentuk place, artinya ruang tersebut memberikan makna dan manfaat karena sering digunakan.
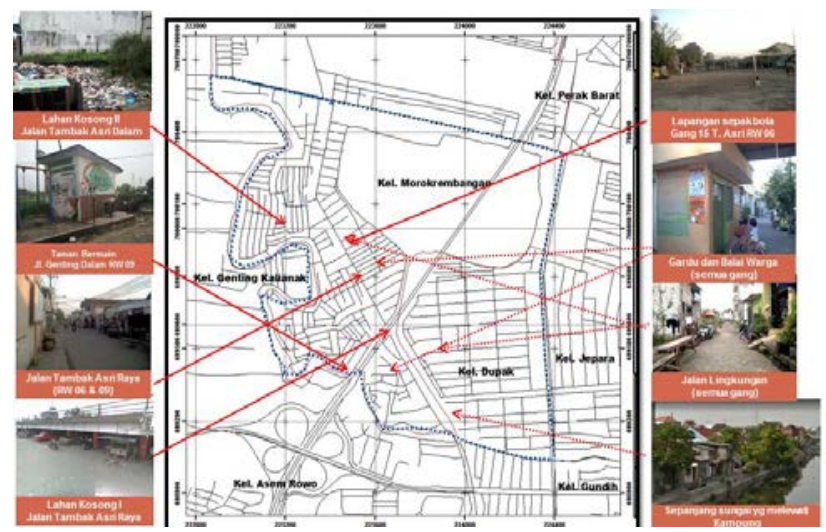

Gambar 7. Aktivitas Sosial dalam Dimensi Intensitas

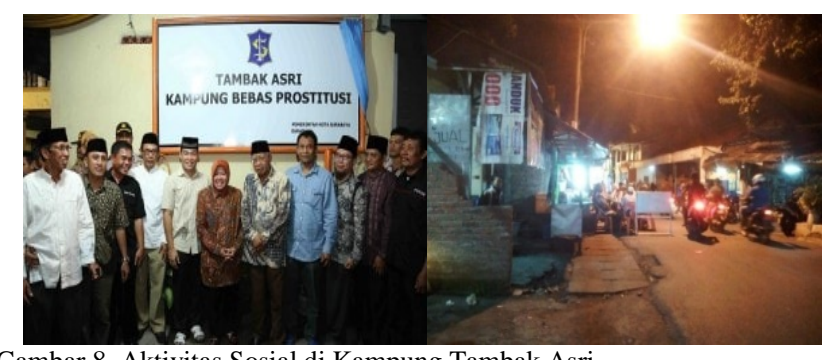

Gambar 8. Aktivitas Sosial di Kampung Tambak Asri

2. Preferensi Bermukim di Kampung Tambak Asri

Karakteristik preferensi menunjukkan kemampuan dalam memilih kawasan bermukim serta mengupayakan prasarana dan sarana di dalam ruang Kampung sebagai bentuk kebutuhan bermukim.

a) Preferensi Ketersediaan dan Kedekatan Prasarana dan Sarana

Kampung Tambak Asri sebagai kawasan permukiman yang terus berkembang, tentu membutuhkan akses yang memadai terhadap prasarana dan sarana. Respon masyarakat terhadap ketersediaan prasarana di Kampung Tambak Asri menunjukkan 75\% diantaranya berpendapat bahwa prasarana yang meliputi air bersih, sanitasi dan drainase di Kampung Tambak Asri dinilai baik.

Walaupun dengan kepadatan penduduk yang cukup tinggi, ketersediaan prasarana yang sederhananya dianggap masyarakat sudah cukup, mendorong masyarakat untuk dengan yakin memilih Kampung Tambak Asri sebagai kawasan bermukim.

Kaitan lainnya adalah kedekatan dengan sarana umum dalam ruang Kampung seperti sarana kesehatan (puskesmas, balai pengobatan), sarana pendidikan (SD, SMP, SMA), sarana peribadatan, dan pasar dapat dengan mudah diakses karena berlokasi dekat rumah warga dan masih dalam lingkup kawasan kampung). Hasil observasi menampilkan bahwa sarana tersebut disediakan dalam keterbatasan luas lahan atau ruang yang dimiliki di Kampung Tambak Asri. Misalnya tidak ada ruang terbuka yang dapat dijadikan pasar, maka masyarakat menggunakan jalan lingkungan Gang XVII dan Gang XVIII sebagai pasar pada pagi hari. Dan untuk sarana lainnya, juga dibangun di Kampung Tambak Asri sangat dekat dengan rumah warga.

Ketersediaan prasarana dan sarana serta kedekatan dengan sarana tersebut, turut mendukung pilihan masyarakat Kampung Tambak Asri dalam bermukim. Pertimbangan ini menggambarkan adanya acces \& linkage dalam ruang Kampung sebagai space, dimana elemen ini berlangsung secara natural dalam keterbatasan ketersediaan ruang. 


\section{b) Preferensi Kelayakan sebagai Kawasan Bermukim}

Menelusuri data kelayakan bermukim berdasarkan respon masyarakat Kampung Tambak Asri, persentase 90-93\% menjelaskan bahwa Kampung Tambak Asri layak dijadikan sebagai kawasan bermukim dengan alasan diantaranya bahwa kehidupan bertetangga di Kampung mengindikasikan untuk membangun kehidupan bertempat tinggal yang layak. Selain itu, masyarakat juga turut melihat fakta bahwa signifikansi pertumbuhan penduduk menandakan bahwa Kampung Tambak Asri layak sebagai tempat bermukim.

Dalam persepsi kelayakan tersebut, Peneliti menangkap adanya fenomena disparate tendencies dalam memberikan pilihan kelayakan bermukim. Artinya, layak tidaknya untuk bermukim pada kawasan kampung tersebut tidak dinilai pada ukuran kelayakan bermukim pada umumnya melainkan pada aktivitas yang sudah terjadi dan tidak dapat dikembalikan pada ukuran seharusnya. Konkretnya, sudah banyak masyarakat yang bermukim di Kampung Tambak Asri sehingga sulit untuk dinilai tidak layak sedangkan sudah banyak yang memilih bertempat tinggal pada kawasan tersebut sehingga pilihan masyarakat disetir oleh persepsi tersebut

\section{c) Preferensi Kawasan Bermukim berdasarkan Faktor \\ Ekonomi}

Kampung merupakan wujud dari perkembangan permukiman di kawasan perkotaan. Kampung Tambak Asri sebagai bagian dari unit perkotaan yang menampung kebutuhan papan masyarakat. Masyarakat Kampung Tambak Asri didominasi oleh $74 \%$ masyarakat berpendapatan menengah ke bawah. Dan sebagian besar rumah tangga masyarakat Kampung Tambak Asri mempunyai anak lebih dari 2 anak, atau dapat dikategorikan sebagai keluarga inti. Adapun jumlah penghuni rata-rata dalam satu atap berkisar 3-6 orang (1 KK). Hal ini menggambarkan bahwa setiap keluarga memiliki tanggungan yang cukup besar dalam membiayai kebutuhan anggota keluarganya. Sehingga hal ini juga turut berpengaruh terhadap kemampuan memilih kawasan bermukim. Dimana apabila didapati permukiman dengan harga lahan terjangkau maka kawasan tersebut akan menjadi pilihan bermukim walaupun memiliki kepadatan yang cukup tinggi.

Kemampuan memiliki kawasan bermukim berdasarkan faktor ekonomi juga akan membentuk perilaku masyarakat dalam memanfaatkan ruang-ruang yang tersedia di dalam Kampung. Keterbatasan kemampuan pengadaan fasilitas dalam ruang kampung dapat mengindikasikan adanya ruangruang Kampung yang diabaikan dan masyarakat mengalihkan pilihannya pada ruang-ruang yang tidak sesuai dengan tujuan penggunaannya. Hal ini yang terjadi pada Taman Bermain yang direncanakan sebagai place dengan aktifnya aktivitas bermain anak-anak cenderung berpotensi menjadi space karena tidak terdapat manfaat dalam penggunaan ruang tersebut atau diabaikan karena akses dan ketersediaan sarananya. Anak-anak cenderung memilih sempadan sungai sebagai tempat bermain.

3. Pola dan Progresivitas Ruang Kampung

a) Penataan Fisik Ruang Kampung Tambak Asri

Identifikasi dinamika perkembangan dan pembangunan di Kampung Tambak Asri berdampak terhadap bentuk dan tatanan fisik di Kampung Tambak Asri yang dapat dijelaskan sebagai berikut:

1. Pola permukiman di Kampung Tambak Asri berkembang secara linear mengikuti jalan lingkungan.
2. Kepadatan penduduk mengindikasikan adanya kepadatan bangunan, sehingga jarak antar bangunan dan jarak sempadan bangunan berjarak 0 meter. Dan jalan lingkungan (gang-gang kecil) di Kampung Tambak Asri juga memiliki lebar yang kurang memadai yakni 0,5-3 meter

3. Jalan sebagai ruang yang berdampak langsung terhadap aktivitas masyarakat. Adapun sirkulasi akses keluar masuk kawasan Kampung terdapat satu arah sirkulasi

4. Bentuk orientasi bangunan di Kampung Tambak Asri saling berhadapan. Dan untuk permukiman sekitar sempadan sungai, posisi bangunan berorientasi menghadap sungai.

b) Perkembangan Ruang Kampung secara Mandiri dan Bertahap

Kompleksitas dinamika sosial di Kampung Tambak Asri berdampak pada pembangunan yang berlangsung di dalam ruang Kampung. Kini pertumbuhan ekonomi usaha kecil dan menengah sangat pesat berkembang di Kampung Tambak Asri. Konkretnya adanya aktivitas berdagang di sepanjang jalan Tambak Asri Raya yang menghidupkan area jalan lingkungan yang padat tersebut.

Melihat kembali pada rekam jejak Kampung Tambak Asri, yang pernah didapati aktivitas prostitusi sebagai bentuk kriminalitas yang menghidupkan jalan lingkungan tersebut. Kini wajah aktivitas perekonomian masyarakat setempat memberikan kesan positif ruang sepanjang jalan Kampung Tambak Asri. Hal ini sebagai bentuk kemandirian yang dalam pembangunan Kampung Tambak Asri, dimana lahir dari inisiatif perubahan sosial masyarakat setempat.

Bentuk lainnya dari kemandirian pembangunan adalah adanya upaya memperbaiki kondisi fisik lingkungan yang rusak seperti pavingisasi atau perbaikan kampung. Pembangunan fisik ini berlangsung bertahap dengan swadaya masyarakat dalam 3 tahun terakhir ini

Kemandirian pembangunan yang diswadayakan oleh masyarakat dapat menjadi salah satu value mengenai rasa memiliki ruang kampung sebagai kawasan bermukim. Hal ini juga dapat menjadi salah satu faktor pendukung untuk menciptakan place. Dimana masyarakat dapat lebih memperhatikan kondisi ruang kampung karena memiliki sense of belonging terhadap ruang tersebut karena manfaat yang diberikan oleh ruang tersebut.

Deskripsi mengenai karakteristik penggunaan ruang-ruang di Kampung Tambak Asri turut memberikan informasi bahwa untuk mendukung keberlanjutan ruang Kampung Tambak Asri dapat ditindaklanjuti dengan arahan-arahan yang bersifat:

1. Mengubah, artinya didasarkan pada persepsi kondisi fisik, maka ruang-ruang seperti taman bermain, lapangan bola, dan lahan kosong sangat penting untuk dilakukan transformasi dengan esensi “mengubah” agar mengarahkan pada persepsi place.

2. Menguatkan, sifat transformasi dengan esensi menguatkan dapat dilakukan pada ruang-ruang yang sudah mengalami adaptasi fisiologi aktvitas sosial maupun yang mempengaruhi preferensi pengguna dengan hanya menambahkan elemen pelengkap untuk memperkuat esensi place. Misalnya pada ruang jalan lingkungan, balai warga, sempadan sungai, dan gardu 


\section{KESIMPULAN}

Ruang-ruang Kampung Tambak Asri yang menjadi unit sampling beragam memiliki kondisi yang berbeda-beda mencirikan potensi space dan place

Karakteristik adaptasi kondisi lingkungan dalam ruang Kampung

a) Adaptasi kultural,bentuk kenyamanan bertempat tinggal tanpa disadari memberikan makna place karena interaksi sangat kental berlangsung di jalan lingkungan. Sehingga, Adanya sampah yang berserakan bukan lagi menjadi masalah lingkungan selama interaksi antar tetangga dan kenyamanan bermukim masih terjaga.

b) Adaptasi fisiologi aktivitas sosial, digambarkan dengan manfaat penggunaan ruang pada unit sampling dan intensitas penggunaan ruang-ruang kampung Tambak Asri. Sesuai dengan ciri dan karakter Kampung yang identik dengan guyub, sehingga ruang-ruang Kampung sangat dekat dengan aktivitas sosial masyarakat. Intensitas turut memberikan ukuran seberapa dekat interaksi masyarakat dengan ruang yang membentuk place, artinya ruang tersebut memberikan makna dan manfaat karena sering digunakan

Karakteristik preferensi bermukim di Kampung Tambak Asri

a) Preferensi ketersediaan dan kedekatan prasarana dan sarana, etersediaan prasarana dan sarana serta kedekatan dengan sarana tersebut, turut mendukung pilihan masyarakat Kampung Tambak Asri dalam bermukim. Pertimbangan ini menggambarkan adanya acces \& linkage dalam ruang Kampung sebagai space, dimana elemen ini berlangsung secara natural dalam keterbatasan ketersediaan ruang.

b) Preferensi kelayakan sebagai kawasan bermukim, adanya fenomena disparate tendencies dalam memberikan pilihan kelayakan bermukim. Dengan kondisi eksisting kawasan bermukim yang dominan kumuh, masyarakat tetap beranggapan Kampung tersebut bersih karena faktor sudah lama bermukim. Artinya ada ketidakserasian antara sebab akibat preferensi bermukim. c) Preferensi kawasan bermukim berdasarkan faktor ekonomi, Kemampuan memiliki kawasan bermukim berdasarkan faktor ekonomi juga akan membentuk perilaku masyarakat dalam memanfaatkan ruang-ruang yang tersedia di dalam Kampung.

Karakteristik pola dan progresivitas ruang kampung

a) Penataan fisik ruang kampung, identifikasi dinamika perkembangan dan pembangunan di Kampung Tambak Asri berdampak terhadap bentuk dan tatanan fisik di Kampung Tambak Asri

b) Perkembangan ruang kampung secara mandiri dan bertahap, Kemandirian pembangunan yang diswadayakan oleh masyarakat dapat menjadi salah satu value mengenai rasa memiliki ruang kampung sebagai kawasan bermukim. Hal ini juga dapat menjadi salah satu faktor pendukung untuk menciptakan place.

Karakteristik ruang-ruang Kampung Tambak Asri memberikan informasi bahwa untuk mendukung keberlanjutan ruang Kampung Tambak Asri dapat ditindaklanjuti dengan arahan-arahan yang bersifat mengubah dan menguatkan menuju place

\section{DAFTAR PUSTAKA}

[1] S. Sumintarsih and A. Adrianto, Dinamika kampung kota Prawirotaman dalam perspektif sejarah dan budaya. Yogyakarta: Balai Pelestarian Nilai Budata Yogyakarta, 2014.

[2] A. N. Iswari, "Strategi dinas kebersihan dan pertamanan kota surabaya dalam pengelolaan ruang terbuka hijau (RTH) untuk mewujudkan pembangunan berkelanjutan dan berwawasan lingkungan,” Kebijak. dan Manaj. Publik, vol. 4, no. 4, 2012.

[3] Badan Pusat Statistik Kota Surabaya, Kecamatan Krembangan dalam Angka 2015. Surabaya: Badan Pusat Statistik Kota Surabaya, 2015.

[4] Project for Public Spaces (PPS) and UNHABITAT, Placemaking and the future of cities. Project for Public Spaces (PPS); UNHABITAT, 2012.

[5] Y. Tuan, Space and place: the perspective of experience. Minneapolis: University of Minnesota Press, 1977.

[6] Sugiyono, Metode Penelitian Pendidikan: Pendekatan Kuantitatif, Kualitatif dan R\&D. Bandung: Alfabeta, 2006.

[7] R. Gifford, Environmental psychology: principles and practice. Boston: Allyn and Bacon, 1987. 